\title{
Risk-based assessment model of the state and municipal procurement system
}

\author{
Elena Karanina ${ }^{1}, K_{\text {Senia Kartavy }}{ }^{{ }^{*}}$ \\ ${ }^{1}$ Vyatka State University, Moskovskaya str., 36, Kirov, 610000, Russia
}

\begin{abstract}
Every year, the volumes of funding in the sphere of provision of state and municipal demand increases significantly. Achieving the effectiveness of government contracts is one of the main and "eternal" problems of public funds management. For public procurement to be effective, it is necessary to meet the needs of the relevant actors, i.e. society, the state, and the private sector. In order to make a qualitative forecast of the results of public procurement placement, the development and implementation of measures aimed at improving the public procurement system, it is necessary to assess the current situation of manifestation of risks arising from the procurement of goods, works and services for state and municipal needs. For this purpose, a risk-based model for assessing the system of state and municipal procurement has been developed, which allows disclosing the nature of the risks of the procurement cycle fully and identifying a case scenario for choosing a way to loss minimization.
\end{abstract}

\section{Introduction}

The system of state (municipal) procurements is the basic component of a market economy. At the same time, the main source of the state demand financing has been and remains the budget funds. More than a third of the expenses of the consolidated budget of the Russian Federation accounts annually for the purchase of products (services, works) for state and municipal needs. The proportion is even greater in developed foreign countries. Therefore, the quality and efficiency of the distribution of state budget resources is largely determined by the effectiveness of the contractual system in the sphere of procurement of goods, works, services for state and municipal needs.

At the same time, the analysis of numerous works devoted to the problems of organization and functioning of the state procurement activities shows that the issues of risk management in state (municipal) procurement remain insufficiently explored. Considering the fact that risk is an integral characteristic of almost any financial and economic activities, it can be stated that the sphere of the state procurement is not an exception in this aspect.

\section{Materials and Methods}

\footnotetext{
* Corresponding author: Kartavyh12@mail.ru
} 
The process of managing the risks arising from the placement of state orders is a systematic approach to the risk events minimization which may in any way affect the achievement of key procurement project objectives.

The method of risk management in state (municipal) procurements is determined by the nature of its occurrence. In general, the risk management algorithm is as follows:

1) identification of the possible consequences of economic activity in a risky situation;

2) development of measures not allowing, preventing or reducing (minimizing) damage -the impact of unforeseen risk factors;

3 ) the implementation of such a system of adapting state and municipal customers to risks, by which not only negative consequences can be neutralized or compensated, but also chances of obtaining a positive effect are made maximum use of [1].

Procurement is a system that includes a large number of central, controlling and supporting processes, having as:

the main external input need for goods, works, services meeting the requirements of the state or society

and the main external output - state's or society's satisfaction with the fulfilled procurement, i.e. satisfied need (Figure 1).

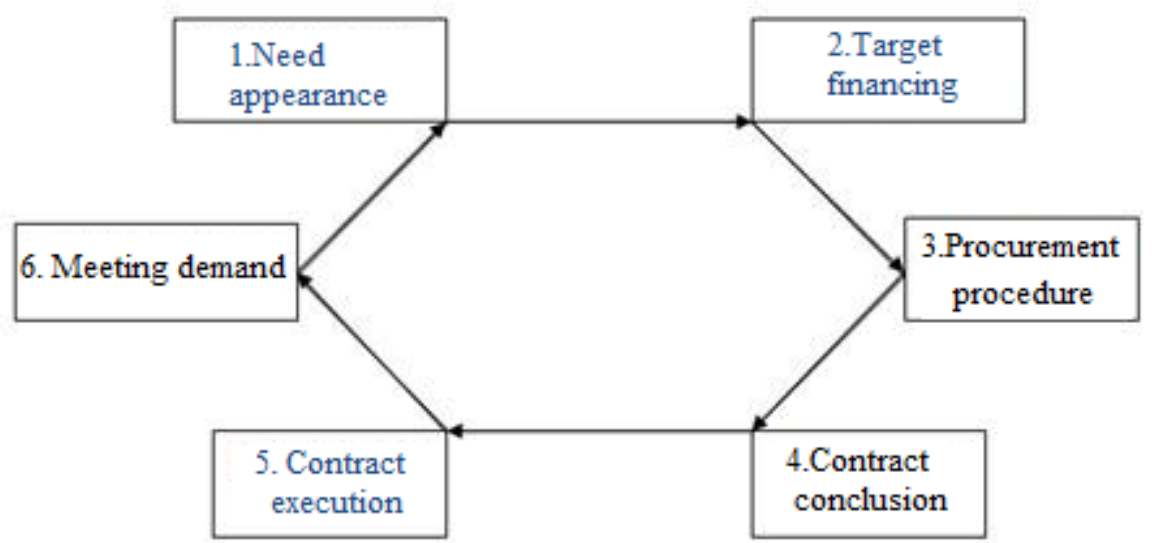

Fig. 1. Procurement cycle

In order to make a qualitative forecast of the results of the state procurement placement, the development and implementation of measures aimed at improving the public procurement system, it is necessary to assess the current situation of risk manifestation appearing by the procurement of goods, works and services for state and municipal needs.

As a result of the risk analysis of procurement activities in the Russian Federation, a classification, description, forecast of the consequences and frequency of risk occurrence in the procurement cycle, as well as risk management impacts have been developed (Table 1, Table 2). 
Table 1. Risk-based assessment model of the state and municipal procurement system

(Risk indicators of the procurement process)

\begin{tabular}{|c|c|c|c|c|}
\hline $\begin{array}{l}\text { Procurement cycle } \\
\text { risks }\end{array}$ & Risk indicators & Units & $\begin{array}{l}\text { Threshold } \\
\text { value }\end{array}$ & $\begin{array}{c}\text { Expert risk } \\
\text { assessment } \\
\text { by degree of } \\
\text { impact on } \\
\text { economic } \\
\text { security in } \\
\text { points from } 1 \\
\text { to } 5\end{array}$ \\
\hline \multirow{5}{*}{$\begin{array}{l}\text { Unmet need of the } \\
\text { state or municipal } \\
\text { customer }\end{array}$} & $\begin{array}{l}\text { Presence of cases of } \\
\text { application } \\
\text { disagreement with the } \\
\text { founder and regulatory } \\
\text { authorities } \\
\end{array}$ & pcs & 0 & \multirow{5}{*}{5} \\
\hline & $\begin{array}{l}\text { Presence of purchase } \\
\text { cancellation cases }\end{array}$ & pes & $\begin{array}{l}0.66 \% \text { out of } \\
\text { total volume }\end{array}$ & \\
\hline & $\begin{array}{l}\text { Presence of cases of } \\
\text { the contract cancellation } \\
\text { (unilaterally, forensic, } \\
\text { under the agreement of } \\
\text { Parties) }\end{array}$ & pes & $\begin{array}{l}9.75 \% \text { out of } \\
\text { total volume }\end{array}$ & \\
\hline & $\begin{array}{l}\text { Presence of cases of } \\
\text { contract conclusion } \\
\text { evasion }\end{array}$ & pcs & $\begin{array}{l}0.02 \% \text { out of } \\
\text { total volume }\end{array}$ & \\
\hline & $\begin{array}{l}\text { Presence of cases of } \\
\text { failed } \\
\text { auctions ( No bids } \\
\text { submitted) }\end{array}$ & pcs & $\begin{array}{l}49.01 \% \text { out } \\
\text { of total } \\
\text { volume }\end{array}$ & \\
\hline \multirow{6}{*}{$\begin{array}{l}\text { Non-disbursement of } \\
\text { the appropriate funds } \\
\text { in the reporting period }\end{array}$} & $\begin{array}{l}\text { Presence of cases of } \\
\text { procurement procedure } \\
\text { extension }\end{array}$ & pcs & $\begin{array}{l}0.73 \% \text { out of } \\
\text { total volume }\end{array}$ & \multirow{6}{*}{3} \\
\hline & $\begin{array}{c}\text { Presence of } \\
\text { documentation changes, } \\
\text { eliminating } \\
\text { contradictions with the } \\
\text { legislation }\end{array}$ & pcs & $\begin{array}{l}0.07 \% \text { out of } \\
\text { total volume }\end{array}$ & \\
\hline & $\begin{array}{l}\text { Presence of the unified } \\
\text { information system } \\
\text { electronic trading } \\
\text { facility failure }\end{array}$ & pcs & 0 & \\
\hline & $\begin{array}{c}\text { Presence of cases of } \\
\text { purchase failure }\end{array}$ & pcs & 0 & \\
\hline & $\begin{array}{c}\text { Presence of cases of } \\
\text { contract conclusion } \\
\text { evasion }\end{array}$ & pcs & $\begin{array}{l}0.02 \% \text { out of } \\
\text { total volume }\end{array}$ & \\
\hline & $\begin{array}{l}\text { Presence of cases of } \\
\text { failed } \\
\text { auctions ( No bids } \\
\text { submitted) }\end{array}$ & pcs & $\begin{array}{l}49.01 \% \text { out } \\
\text { of total } \\
\text { volume }\end{array}$ & \\
\hline $\begin{array}{l}\text { Restriction on } \\
\text { competition }\end{array}$ & $\begin{array}{l}\text { Requests for } \\
\text { clarification }\end{array}$ & pes & $\begin{array}{l}15.13 \% \text { out } \\
\text { of total } \\
\text { volume }\end{array}$ & 5 \\
\hline
\end{tabular}




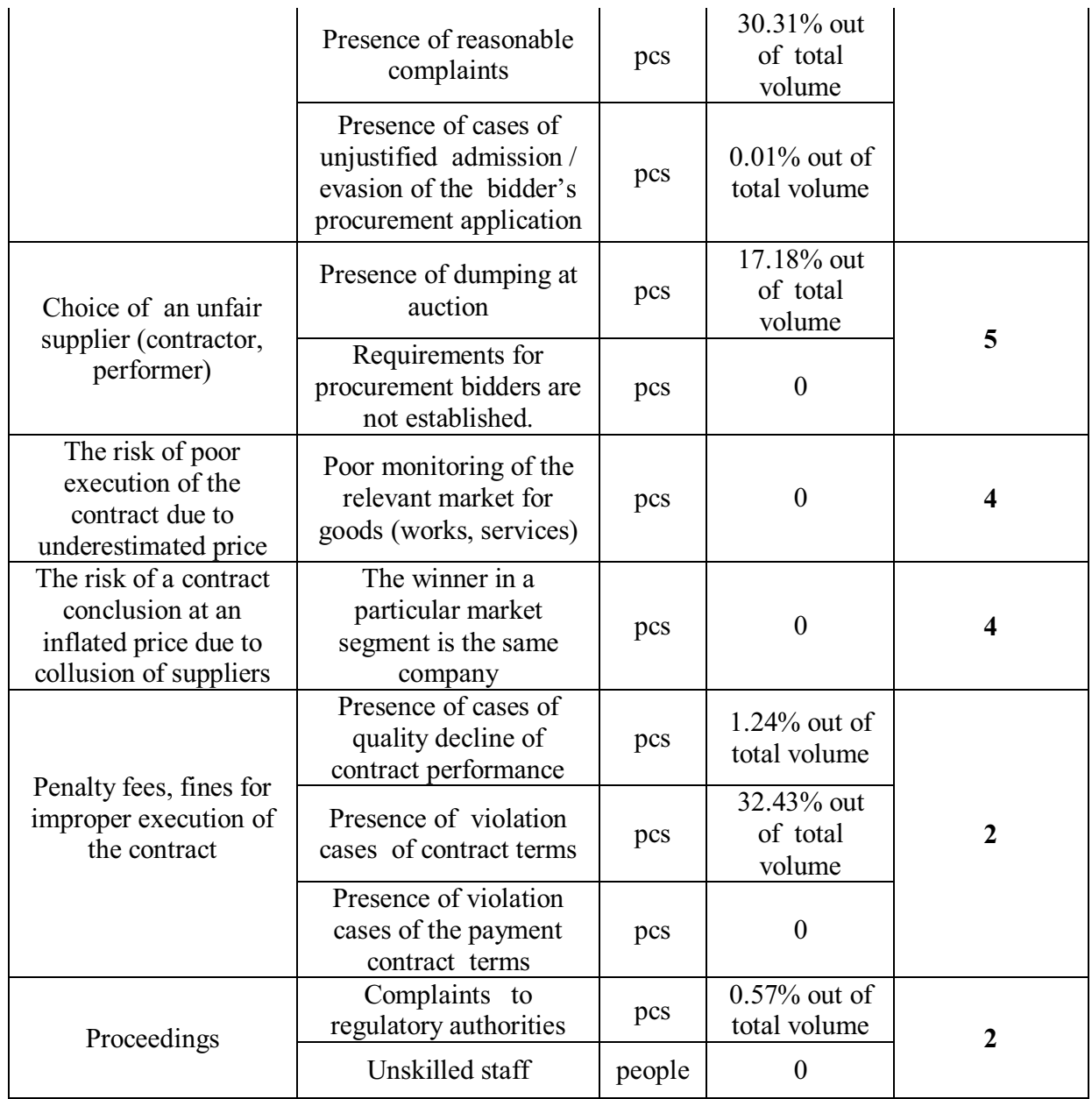

Table 2. Risk-based model of state and municipal procurement system assessment (Elements of procurement process risk description)

\begin{tabular}{|c|c|c|}
\hline $\begin{array}{c}\text { Procurement cycle } \\
\text { risks }\end{array}$ & $\begin{array}{c}\text { Consequences of the } \\
\text { risks }\end{array}$ & Risk management methods \\
\hline $\begin{array}{l}\text { Unmet need of the } \\
\text { state or municipal } \\
\text { customer }\end{array}$ & $\begin{array}{l}\text { The customer cannot fulfill } \\
\text { his functions qualitatively, } \\
\text { timely and fully and solve } \\
\text { the tasks set for him of a } \\
\text { non-commercial nature, for } \\
\text { the common good and } \\
\text { development of citizens. }\end{array}$ & $\begin{array}{l}\text { Organizational: } \\
\text { - selection of employees of } \\
\text { appropriate qualification; } \\
\text { - strict regulation of the interaction } \\
\text { process at all stages of order } \\
\text { formation; } \\
\text { - the introduction of modern tools } \\
\text { and methods of planning, } \\
\text { forecasting, financial and } \\
\text { economic analysis; } \\
\text { - a more profound and better study } \\
\text { of the procurement documentation } \\
\text { Economic: }\end{array}$ \\
\hline
\end{tabular}




\begin{tabular}{|c|c|c|}
\hline & & $\begin{array}{l}\text { - to provide maximum provision } \\
\text { for the contract, application } \\
\text { execution; } \\
\text { - administrative responsibility } \\
\text { (fines, penalties). }\end{array}$ \\
\hline $\begin{array}{l}\text { Non-disbursement } \\
\text { of the appropriate } \\
\text { funds in the } \\
\text { reporting period }\end{array}$ & $\begin{array}{l}\text { Recognition of the subsidy } \\
\text { as ineffective; undisbursed } \\
\text { financial funds come back } \\
\text { to the relevant budget. } \\
\text { The probability of funding } \\
\text { cuts in the next reporting } \\
\text { period is high. }\end{array}$ & $\begin{array}{l}\text { Administrative: } \\
\text { - preliminary selection of } \\
\text { participants for compliance with } \\
\text { the requirements of the legislation; } \\
\text { - to provide the requirement to the } \\
\text { participants of the procurement: } \\
\text { the absence of unfair suppliers in } \\
\text { the register. } \\
\text { Economic: } \\
\text { - to provide maximum security for } \\
\text { the execution of the contract, its } \\
\text { application; } \\
\text { - administrative responsibility } \\
\text { (fines, penalties) } \\
\text { Organizational: } \\
\text { - selection of employees with } \\
\text { appropriate qualifications; } \\
\text { - strict regulation of the interaction } \\
\text { process at all stages of order } \\
\text { formation; } \\
\text { - the introduction of modern tools } \\
\text { and methods of planning, } \\
\text { forecasting, financial and } \\
\text { economic analysis; } \\
\text { - a more profound and better study } \\
\text { of the procurement documentation }\end{array}$ \\
\hline $\begin{array}{l}\text { Restriction on } \\
\text { competition }\end{array}$ & $\begin{array}{l}\text { Reducing the number of } \\
\text { business entities in the } \\
\text { relevant goods market; } \\
\text { unreasonable increase or } \\
\text { decrease in the price of the } \\
\text { goods; refusal of economic } \\
\text { entities from independent } \\
\text { actions; } \\
\text { development of general } \\
\text { conditions for the } \\
\text { circulation of goods in the } \\
\text { market as a result of an } \\
\text { agreement conclusion or } \\
\text { carrying out joint efforts; } \\
\text { provision by the authorities } \\
\text { of unreasonable } \\
\text { requirements for goods or } \\
\text { business entities; }\end{array}$ & $\begin{array}{l}\text { Organizational: } \\
\text { - the study of the relevant market of } \\
\text { goods, works, services; } \\
\text { - selection of the object of } \\
\text { procurement from the market } \\
\text { segment where there is } \\
\text { competition; } \\
\text { - exclusion from the procurement } \\
\text { documentation of provisions } \\
\text { restricting competition; } \\
\text { - selection of employees with } \\
\text { appropriate qualifications; } \\
\text { Economic: fines on employees for } \\
\text { improper performance of their } \\
\text { duties. }\end{array}$ \\
\hline
\end{tabular}




\begin{tabular}{|c|c|c|}
\hline & $\begin{array}{l}\text { customer's administrative } \\
\text { responsibility. }\end{array}$ & \\
\hline $\begin{array}{l}\text { Choice of an unfair } \\
\text { supplier (contractor, } \\
\text { performer) }\end{array}$ & $\begin{array}{l}\text { Improper performance of } \\
\text { the contract, proceedings, } \\
\text { termination of the contract, } \\
\text { Customer 's needs } \\
\text { dissatisfaction }\end{array}$ & $\begin{array}{l}\text { Economic: } \\
\text { - to provide maximum security for } \\
\text { the execution of the contract; } \\
\text { - to provide fines and penalties for } \\
\text { improper performance of the } \\
\text { contract. }\end{array}$ \\
\hline $\begin{array}{l}\text { The risk of poor } \\
\text { execution of the } \\
\text { contract due to } \\
\text { underestimated price }\end{array}$ & $\begin{array}{l}\text { Ineffective spending of } \\
\text { budgetary funds, non- } \\
\text { fulfillment (poor-quality } \\
\text { implementation) of set } \\
\text { state tasks. }\end{array}$ & $\begin{array}{l}\text { Organizational: } \\
\text { - selection of employees with } \\
\text { appropriate qualifications; } \\
\text {-strict regulation of the interaction } \\
\text { process at all stages of order } \\
\text { formation; introduction of modern } \\
\text { tools and methods for analyzing the } \\
\text { market for goods, works, services; } \\
\text { Economic: } \\
\text { - fines on employees for improper } \\
\text { performance of duties. }\end{array}$ \\
\hline $\begin{array}{l}\text { The risk of a } \\
\text { contract conclusion } \\
\text { at an inflated price } \\
\text { due to collusion of } \\
\text { suppliers }\end{array}$ & $\begin{array}{l}\text { Ineffective spending of } \\
\text { budgetary funds. }\end{array}$ & $\begin{array}{l}\text { Organizational: } \\
\text { - the study of the relevant market of } \\
\text { goods, works, services; } \\
\text { - selection of the procurement } \\
\text { object from the market segment } \\
\text { where there is competition; } \\
\text { - exclude provisions restricting } \\
\text { competition from the procurement } \\
\text { documentation. }\end{array}$ \\
\hline $\begin{array}{l}\text { Penalty fees, fines } \\
\text { for improper } \\
\text { execution of the } \\
\text { contract }\end{array}$ & $\begin{array}{l}\text { Claim work, financial and } \\
\text { temporary losses, } \\
\text { inefficient expenditure of } \\
\text { financial funds. }\end{array}$ & $\begin{array}{l}\text { Economic: } \\
\text { - to provide maximum provision } \\
\text { for the contract execution; } \\
\text { - to charge fines and fees for } \\
\text { improper contract execution. } \\
\text { Organizational: } \\
\text { - procurement is carried out if only } \\
\text { funding is available; } \\
\text {-introduction of modern tools and } \\
\text { techniques for planning, } \\
\text { forecasting and financial and } \\
\text { economic analysis. }\end{array}$ \\
\hline Proceedings & $\begin{array}{l}\text { Administrative } \\
\text { responsibility in the form of } \\
\text { a fine; inefficient } \\
\text { expenditure of financial } \\
\text { funds. }\end{array}$ & $\begin{array}{l}\text { Organizational: } \\
\text { - selection of employees of } \\
\text { appropriate qualification; } \\
\text { - strict regulation of the interaction } \\
\text { process at all stages of order } \\
\text { formation; } \\
\text { - the introduction of modern tools } \\
\text { and methods of planning, } \\
\text { forecasting and financial and } \\
\text { economic analysis; }\end{array}$ \\
\hline
\end{tabular}




\begin{tabular}{|l|l|l|}
\hline & $\begin{array}{l}\text { - a more profound and better- } \\
\text { quality study of special provisions } \\
\text { in the contract projects. } \\
\text { Economic: } \\
\text { - fines on employees for improper } \\
\text { performance of their duties. }\end{array}$ \\
\hline
\end{tabular}

Thus, the risk-based assessment model of the system of state and municipal procurement of the Russian Federation includes six elements describing the risks arising during the placement of the government orders:

1) "The name of the procurement cycle risk";

2) "Possible risk indicators";

3) "The probability of risk occurrence";

4) "The consequences of risk occurrence";

5) "Methods of risk management."

Using a risk-based model, the probability of risk occurrence is determined as follows:

If the indicator value is "less" or "equal" to the "Threshold value", then the probability of risk occurrence is low $(0 \%)$;

If the indicator values are "higher" than the "Threshold value", then the probability of risk occurrence is high, that is, $100 \%$.

The main goal of state and municipal procurement is to meet the federal needs, the needs of the constituent entities of the Russian Federation and the municipal needs, that is, the state order is placed for:

1) achieving goals and implementation measures stipulated by state programs of the Russian Federation (including federal target programs, other documents of strategic and goal-oriented planning of the Russian Federation), state programs of constituent entities of the Russian Federation (including regional target programs, other documents of planning of subjects of the Russian Federation), municipal programs;

2) the fulfillment of international obligations of the Russian Federation, the implementation of interstate target programs, a participant of which the Russian Federation is;

3) performance of functions and powers of state bodies of the Russian Federation, government bodies of state off-budget funds of the Russian Federation, state bodies of constituent entities of the Russian Federation, government bodies of territorial off-budget funds, municipal bodies [2].

It is necessary to emphasize the risk of dissatisfaction with the needs of state (municipal) customers, which by the volume of consequences significantly exceeds other risks. Upon the occurrence of a negative event, customers will not be able to fulfill their functions and solve the tasks set for them of a non-commercial nature qualitatively, timely and fully for the common good and development of citizens.

Risk management is the process of making and implementing management decisions aimed at reducing the probability of an adverse effect occurrence and minimizing potential losses caused by its implementation. To reduce the risks when placing the state order, appropriate measures are developed.

Organizational methods of procurement cycle risk management:

- selection of employees with appropriate qualifications;

- strict regulation of the interaction process at all stages of order formation;

- the introduction of modern tools and methods of planning, forecasting, financial and economic analysis;

- more profound and qualitative study of documentation on procurement;

- the study of the relevant market of goods, works, services;

- the selection of the purchase object from the market segment where there is competition;

- exclusion of provisions restricting competition from the documentation on the procurement; 
- procurement only subject to funding.

Administrative methods of risk management in the system of state (municipal) procurement include:

- preliminary selection of procurement participants to comply with the requirements of the law;

- the availability of requirements to procurement participants: the absence of unfair suppliers in the register,

Economic methods of risk management in procurement for state and municipal needs include:

- maximum provision of the contract fulfillment, applications for participation in the tender procedure;

- management responsibility (fines, penalties) for non-performance or improper performance of the state contract;

- management responsibility in the form of a fine on a contracting officer for improper performance of his official duties [4].

\section{Results}

Experimental testing of the risk-oriented model was carried out on the example of the system of state and municipal procurements of the Volga Federal District of the Russian Federation (hereinafter referred to as the VFD) in the context of its 14 constituent entities based on 2018 analytical and statistical data:

1. The republic of Bashkortostan;

2. Kirov region;

3. The republic of Mari El;

4. The republic of Mordovia;

5. Nizhny Novgorod region;

6. Orenburg region;

7. Penza region;

8. Perm region;

9. Samara region;

10. Saratov region;

11. The republic of Tatarstan;

12. Udmurt republic;

13. Ulianovsk region;

14. Chuvash republic.

The results of the analysis have shown that most of the problems in the procurement cycle arise during the execution of the contract, as evidenced by the high percentage of contract cancellations and claim handling. All 14 subjects of the Volga Federal District run a high probability of risk in restricting competition in the implementation of procurement. This fact, in turn, is a sign of corruption and should attract attention of the legislator in the field of public procurement. The high corruption component of public procurement is also evidenced by a large number of complaints to regulatory authorities regarding compliance with the law on the Contractual system in the procurement field when placing the state order.

\section{Discussion}

The conclusion of contracts for state and municipal needs accounts for a significant share of the Volga Federal District budget and therefore the task of efficiently using the funds allocated for these purposes, which can be solved first of all under the condition of efficiently 
placing the state order, acquires particular urgency. Financial resources have a certain limit, and in the conditions of the current financial crisis, this issue has become especially urgent, since it must be a question of balancing the budget and economic security.

With every year, volumes of financing in the field of state and municipal contract increase significantly. The effectiveness of government contracts is one of the main and "eternal" problems of public resource management. According to experts, "in order for public procurement to be effective, it must meet the needs of the relevant actors, that is, the society, the state, and the private sector."

At the same time, recognizing the absolute importance of improving the procurement institution, I would like to emphasize that the formation of a federal contract system must have the goal of not only effectively implementing the function of meeting the needs of state (public) consumption, but also the function of economic security. In the modern mixed economy, the state acts as the largest customer and consumer of products from a wide range of industries, which makes it possible to transform the government demand into a powerful tool of regulating the economy, influencing its dynamics and structure, as well as, for solving strategic tasks of the country's development. Therefore, within the framework of this study, it would be logical to determine the extent to which the risks of the procurement cycle of state and municipal customers of the Volga Federal District affect economic security. For these purposes, a survey was conducted among procurement experts: 806 experts procurement specialists from various state and municipal institutions of the Volga Federal District were interviewed. All respondents noted the presence of specified risks in the practice of government order allocation and provided an expert assessment of risks according to the degree of impact on economic security under a scale from 1 to 5 points.

The survey results have shown a high degree of impact on the economic security of such risks as:

- unmet need of the state or municipal customer;

- restriction on competition;

- choice of unfair supplier (contractor, performer).

The analysis results are explained by the fact that the economic security in the sphere of state procurement is, first of all, strictly targetted and efficient use of budget funds, the observance of the necessary quality of supplied goods (services provided, carried out works), the fullest possible use of the provision of competitive bids in the choice of state order performers, counteraction to criminal-corruption distribution of threats.

\section{Conclusions}

Summing up, it should be noted that the risk analysis of allocating of the state and municipal orders of the Russian Federation allows to disclose fully the nature of the risks of the procurement cycle occurrence and to identify a case scenario for choosing a way of minimizing losses. The risk-based model for assessing the state (municipal) procurement system demonstrated the interrelation of risks not only by the totality of procedures of one process, but also by the influence of the risks of some processes on the manifestation of risks of other processes. That is, the risks are systemic in nature, and the manifestation of one of them in most cases causes a synergistic effect and the manifestation of a number of other risks according to the snowball sampling model. However, this phenomenon is not universal and specific for different risk groups.

\section{References}


1. L. Domracheva, E. Karanina, A. Bakhtimov, M. Kochetkov, MATEC Web of Conferences, 193, 05067 (2018)

2. E. Karanina, O. Ryazanova, N. Gritsuk, MATEC Web of Conferences, 193, 01031 (2018)

3. E. Karanina, K. Kartavyh, MATEC Web of Conferences, 170, 01003 (2018)

4. T. Marinchenko, Journal of VNIIMZH, 2, 204 (2017)

5. S. N. Shirokov, T. I. Pisarenko, T. P. Kutuzova, ISPSAU, 3, 168 (2017)

6. E. Karanina, E. Sapozhnikova, D. Loginov, A. Holkin, E. Sergievskaya, A. Zurakhovskii, MATEC Web of Conferences, 106 (2017)

7. A. I. Altukhov, Economist, 8, 30 (2014)

8. L. A. Kormishkina, N. N. Semenova, Digest Finance, 2, 61 (2015)

9. V. I. Savkin, Vestnik OrelGAU, 6, 26 (2016)

10. E. Karanina, O. Ryazanova, A. Timin, EMMFT, 692 (2017) 